\title{
STUDIES ON THE MECHANISM OF PATHOGENICITY OF NEISSERIA GONORRHOEAE
}

\author{
P. Novotny, J. A. Short, M. Hughes, Jarmila J. Miler, Christine Syrett, \\ W. H. TURNer, J. R. W. HARris* AND I. P. B. MACLENNAN*
}

Wellcome Research Laboratories, Department of Bacteriology, Beckenham, Kent, BR3 3BS and * Alexandra Clinic, St Giles' Hospital, King's College Teaching Group, London SE5 9RS

\section{Plates XXI-XXVIII}

IT has been shown that cells of Neisseria gonorrhoeae make close contact with host cells under natural conditions (Ward and Watt, 1972) and under experimental conditions (Swanson, 1973). These findings are in accordance with the general view on the organism's mechanism of pathogenicity at mucosal surfaces as reviewed by Smith (1964 and 1972).

It has been assumed that gonococcal pili are associated with virulence, enabling the individual cocci to anchor themselves to the mucosa (Ward, Watt and Robertson, 1974) or making gonococci resistant to phagocytosis (Swanson, Kraus and Gotschlich, 1971; Punsalang and Sawyer, 1973; Thongthai and Sawyer, 1973; Ofek, Beachey and Bisno, 1974). These assumptions resulted from the observation that " virulent " $T_{1}$ and $T_{2}$ colonial forms of gonococci have been found to be pilate (Jephcott, Reyn and Birch-Anderson, 1971; Swanson et al., 1971) whereas " avirulent" forms were non-pilate.

Certain facts suggest that the association of pili with virulence may be only apparent. (1) The appendages may be seen to be in contact with a supporting surface, but this does not necessarily indicate active adhesion. (2) Gonococci studied in urethral pus possess relatively few pili (Novotny, Short and Walker, 1975). (3) Pilar antibodies neither confer immunity nor interfere with the virulence of challenge in the infection of subcutaneous chambers in guineapigs (Turner and Novotny, 1976).

Although there is no certainty that immunity in guinea-pigs is a valid model for the immune state in man, the role of pili in adhesion has also been found to be unimportant in the attachment of gonococci to human spermatozoa (James-Holmquest et al., 1974) and to human polymorphs (Swanson et al., 1975).

In our studies of pus from patients with gonorrhoea (Novotny, Short and Walker, 1975) gonococci were seen apparently multiplying in special clusters called infectious units. Evidence suggested that these were formed inside phagocytic cells and had a specific affinity for epithelial cells. This paper presents further data on the infectious units and postulates that their formation is an expression of the pathogenicity of gonococci and that gonorrhoea appears to be a specific disease of human macrophages.

\section{MATERIALS AND METHODS}

\section{Gonococci}

Cultures. Three methods were used. (a) Growth on GC medium, solid or liquid, as described previously (Novotny, Short and Walker, 1975). (b) For primary isolation, growth

Received 14 Sept. 1976; revised version accepted 25 Jan. 1977. 
on GC plates containing V-C-N inhibitor (BBL) at the recommended concentration (i.e., Thayer-Martin medium without haemoglobin). (c) Growth was obtained by the technique of Gibbs and Roberts (1975) modified so that only one 18-24 h static culture preceded injection into the allantois of fresh embryonated eggs (10 days, White Leghorn) shaken on a Kühner Orbital Shaker (Kühner, Basel, Switzerland, type RC 5SP) at 150 r.p.m. and a radius of $5 \mathrm{~cm}$. The gonococci grew to a concentration of $10^{106}-10^{8}$ colony-forming units per $\mathrm{ml}$ after incubation for $5 \mathrm{~h}$.

In guinea-pig experiments with colchicine and vinblastine, strain Pat 1 of $N$. gonorrhoeae was used (Novotny, Short and Walker, 1975). This strain had been subcultured 20-28 times on artificial media as $\mathbf{T}_{2}$ colonial forms.

For the detection of antibodies in sera of patients with gonococcal septicaemia, the infecting strains isolated from the urethra (U) or cervix (C) or both were used as antigen and the strains are designated StG 127C, 127U, 128C, 128U, 176C ahd 176U. All of these strains required arginine, hypoxanthine and uracil for growth. The StG 47 isolate originated from a male infecting the patient StG 58, and was used in place of the strain StG 58 as the isolate from the female was not available. In all cases the colonies from primary cultures on GC medium with V-C-N inhibitor were resuspended in a protective medium containing glycerol (Turner and Novotny, 1976) and kept in a liquid nitrogen refrigerator (LR-40, Union Carbide). When the primary culture was too contaminated, isolates were stored as a first subculture. In no case was only a single colony subcultured, and passaging of $T_{3}$ colonies was avoided as much as possible. To obtain seeds from frozen suspensions a technique similar to that described by Bullen (1975) allowed us to obtain seeds without thawing the master suspension and made it possible to use the first to the third subculture on artificial media in our experiments.

Collection of specimens from patients was as described previously (Novotny, Short and Walker, 1975).

\section{Experiments with chambers in guinea-pigs}

Chambers in guinea-pigs were prepared and infected as previously reported (Turner and Novotny, 1976). Strain Dunkin-Hartley (Charles River) guinea-pigs (c. $800 \mathrm{~g})$ were used.

Enumeration of colony forming units (c.f.u.) was done as reported previously by Novotny and Brookes (1975). The chamber liquid was diluted with saline and GC plates were used for the counts.

The following methods were used to examine the chamber fluid.

Measurement of redox potential. An agar- $\mathrm{KCl}$ bridge was made with an intravenous catheter (Bardic I-Catheter, Bard, Clacton-on-Sea, Essex) filled with $2 \%$ agar containing $3 \mathrm{~N} \mathrm{KCl}$. After checking the conductivity of this agar bridge, one end of the catheter was introduced into the chamber through a needle which was then withdrawn. The other end of the agar bridge was immersed in a beaker containing $3.5 \mathrm{~N} \mathrm{KCl}$ in which a $3.5 \mathrm{~N}$ calomel electrode was also immersed. The miniature platinum electrode was made of a straight platinum wire $(0.25 \mathrm{~mm}$ diameter) sealed in a glass capillary tube introduced into the chamber in the same way as the catheter. The Pt electrode was inserted into a hole on the side of the chamber opposite the agar bridge and the needle was withdrawn leaving it in place. The measuring instrument was a Radiometer TTT2b titrator. To the values determined, $+0.236 \mathrm{~V}$ was added to obtain the value of the standard hydrogen electrode. The agar bridge as well as the Pt electrode was suitable for redox measurement in the heart of a narcotised guinea-pig.

Determination of lysozyme (EC.3.2.1.17). The method of Jollès (1962) was used. The standard was crystalline lysozyme, activity c. 15000 units per mg (Koch and Light Laboratories). Freeze-dried cells of Micrococcus lysodeikticus suspended in the recommended buffer to an appropriate density served as a substrate. The chamber contents were spun down to remove the bacteria and host cells and the supernate $(0.1 \mathrm{ml})$ was used for testing. The values of increasing transmittance were compared with the activity of lysozyme chloride solutions containing $0.33,0.66$ and $1.23 \mu \mathrm{g}$ per $\mathrm{ml}$ of the reacting mixtures. The samples were incubated in a water bath at $25^{\circ} \mathrm{C}$ and readings were made with a Coleman 
Junior II spectrophotometer at $650 \mathrm{~nm}$ after incubation for $180 \mathrm{~s}$. The concentration of natural lysozyme in $0.1 \mathrm{ml}$ guinea-pig serum was not detectable by this technique since no increase in transmittance occurred within $180 \mathrm{~s}$ although there was some increase after incubation for $30 \mathrm{~min}$.

Determination of phosphatases. Acid (EC.3.1.3.2) and alkaline (EC.3.1.3.1) phosphatases were determined in the supernates of chamber liquid after spinning at $1000 \mathrm{~g}$ for $20 \mathrm{~min}$. (Michell, Karnovsky and Karnovsky, 1970) with p-nitrophenyl phosphate as substrate (Koch and Light Laboratories, No. $4286 \mathrm{t}$ ). The amounts of enzymes determined at $37^{\circ} \mathrm{C}, p \mathrm{H} 4.8$ for acid phosphatase and at $25^{\circ} \mathrm{C}, p \mathrm{H} 8.8$ for alkaline phosphatase, are expressed as $\mu$-moles of $p$-nitrophenyl phosphate hydrolysed per $\mathrm{ml}$ of the exudate per min.

Complement was determined by the micromethod of Wasserman and Levine (1961) with guinea-pig complement (Wellcome Reagents Ltd) as standard. The samples represented chamber specimens from 20 guinea-pigs with infected chambers and 18 guinea-pigs before infection. None of the samples from infected chambers had anti-complementary activity as determined at a 1.25 haemolytic unit level.

Histology of the guinea-pig tissue. The guinea-pig was exsanguinated, the chamber was removed through an incision and the surrounding tissue was sliced with a scalpel into blocks c. $5 \times 20 \times 10 \mathrm{~mm}$. The tissue blocks were fixed in $10 \%$ formalin and embedded in paraffin wax.

Colchicine (Sigma) was dissolved immediately before use to the appropriate concentration in sterile saline and the solution was stored in the dark until used (within about $\mathbf{3 0} \mathrm{min}$. of preparation).

Vinblastine sulphate (Sigma) was also dissolved in sterile saline and used immediately.

\section{Buffers}

Phosphate buffered saline (PBS) was $123 \mathrm{mM} \mathrm{NaCl}, 10 \cdot 4 \mathrm{mM} \mathrm{Na}_{2} \mathrm{HPO}_{4}, 3 \cdot 16 \mathrm{mM} \mathrm{KH}_{2} \mathrm{PO}_{4}$, $p \mathrm{H} 7 \cdot 2$.

Phosphate buffered saline with chlorhexidine gluconate (PBSH) contained $0.002 \% \mathrm{v} / \mathrm{v}$ "Hibitane" (ICI).

Phosphate buffer was $57 \mathrm{mM} \mathrm{K}_{2} \mathrm{HPO}_{4}, 30 \mathrm{mM} \mathrm{KH}_{2} \mathrm{PO}_{4}, p \mathrm{H} 7 \cdot 2$.

$0.5 \mathrm{M}$ Tris- $\mathrm{HCl}$ buffer was $500 \mathrm{mM}$ Tris-hydroxymethyl-methylamine $\mathrm{HCl}$ (Koch and Light Laboratories) adjusted to $p \mathrm{H} 7.6$ by $\mathrm{HCl}$.

\section{Antisera}

Human sera were obtained from four patients with gonococcal septicaemia during the acute and convalescent phases of the disease.

Antigonococcal rabbit sera against $\mathrm{T}_{2}$ and $\mathrm{T}_{4}$ colony forms of strain Pat 1 were prepared as described previously (Novotny and Turner, 1975).

Rabbit antiserum against human phagocytes. Isolated human phagocytes from peripheral blood were prepared according to van Furth, Schuit and Hijmans (1966) and were kindly supplied by Dr Lida Ivanyi (Department of Oral Immunology and Microbiology, Guy's Hospital). The final preparation contained $95-97 \%$ phagocytes and was treated as follows approximately $4 \mathrm{~h}$ after bleeding. The cells were suspended to a density of $2 \times 10^{7}$ cells per ml in Park 199 medium and the granules and organelles freed according to the method of Depierre and Karnovsky (1973). The disintegrated slurry was made isotonic by the addition of $\mathrm{NaCl}$ and concentrated to half of its original volume by spinning at $10000 \mathrm{~g}$. It contained membranes, small granules, organelles and nuclei with some whole cells and was divided into two portions. One was mixed with an equal volume of Freund's complete adjuvant and contained an equivalent of $2 \times 10^{7}$ cells per $\mathrm{ml}$; the other, which contained the equivalent of $3 \times 10^{7}$ cells, received a half-volume of $\mathrm{M} \mathrm{NaHCO}_{3}$ and one volume of PBS followed by dropwise addition of one volume of $10 \% \mathrm{w} / \mathrm{v}$ potassium alum. The mixture was left overnight at $4^{\circ} \mathrm{C}$, centrifuged for $30 \mathrm{~min}$. at $3000 \mathrm{~g}$ and the precipitate resuspended in $4 \mathrm{ml}$ of PBS. Both antigens were frozen at $-100^{\circ} \mathrm{C}$ when not in use. Rabbits received two 
1-ml doses of the antigen in Freund's complete adjuvant intramuscularly at an interval of 2 weeks. Seven days after the second injection the rabbits were hyperimmunised by intravenous injections with the alum-precipitated antigen. The animals received six doses starting at $0.05 \mathrm{ml}$ and increasing to $0.4 \mathrm{ml}$ injected at intervals of 3-4 days; 14 days after the last injection the rabbits were bled.

The $\gamma$ globulin from this serum when coupled with fluorescein isothiocyanate was found to label human lymphocytes, polymorphs and macrophages as well as the granules obtained as above at a dilution of 240 . The serum did not react in a ring test with normal human $\gamma$ globulin and it did not form precipitation lines in agar against normal human sera.

Labelling of sera with 125I. Rivanol-purified IgG $(5 \mu \mathrm{g})$ was iodinated with carrier-free Na125I (Radiochemical Centre, Amersham, England) by a modification of the chloramin $\mathrm{T}$ procedure of Hunter (1973) to a specific activity of $c .70 \mu \mathrm{C}$ per $\mu \mathrm{g}$. Free iodine was separated from the labelled protein by passage through a column of Sephadex G15 (Pharmacia, London W4) and collected in $0.5 \% \mathrm{v} / \mathrm{v}$ normal rabbit serum. Only fractions from which $>97 \%$ of the radioactivity could be precipitated with $10 \% \mathrm{w} / \mathrm{v}$ trichloroacetic acid were used.

Conjugation of sera to horseradish peroxidase. Antisera were labelled with horseradish peroxidase (Koch Light Laboratories) according to the technique described by Avrameas and Ternynck (1971).

\section{Electron microscopy}

Immune electron microscopy was as previously described (Novotny and Turner, 1975) with serum obtained from patients suffering from gonococcal septicaemia. The antigens were cells harvested from GC plates, cells centrifuged from GC liquid medium or cells harvested from the allantoic fluid of embryonated eggs. For the detection of antibodies in the chamber contents, the exudates were centrifuged at $40000 \mathrm{~g}$ for $30 \mathrm{~min}$.

Ultrathin sections of pus samples were made as described by Novotny, Short and Walker (1975), but the primary fixative was glutaraldehyde-acrolein (Burdett and Murray, 1974).

The use of the peroxidase-coupled antisera. Pus previously fixed in $2 \% \mathrm{v} / \mathrm{v}$ glutaraldehyde in phosphate buffer $(p H$ 7.2) was washed several times in PBS over a period of $18 \mathrm{~h}$ to remove residual fixative. The relevant peroxidase-conjugated antiserum $(0.5 \mathrm{ml})$ was added to the washed pus and incubated at $37^{\circ} \mathrm{C}$ for $2 \mathrm{~h}$. The samples were washed several times in PBS to remove excess conjugate. A mixture of $170 \mathrm{ml}$ of $0.5 \mathrm{M}$ Tris- $\mathrm{HCl}$ buffer at $p \mathrm{H} 7 \cdot 6,22 \mathrm{mg}$ of $3 \cdot 3^{\prime}$ diaminobenzidine tetra $\mathrm{HCl}$ (Koch Light Laboratories), and $1.5 \mathrm{ml}$ of $0.3 \% \mathrm{v} / \mathrm{v}$ hydrogen peroxide $(\mathrm{BDH})$, was made immediately before use and filtered through two sheets of Whatman No. 1 filter paper. Portions of it $(c .10 \mathrm{ml})$ were placed on the pelleted sample $(c .0 .05 \mathrm{ml})$ which was then resuspended. After $3 \mathrm{~min}$, the mixture was diluted 10 times with $0.5 \mathrm{M}$ Tris buffer $(p \mathrm{H} \mathrm{7.6)}$ and rapidly centrifuged. The pellet was washed at least six times with identical buffer. The pus was then transferred to $1 \% \mathrm{v} / \mathrm{v}$ osmium tetroxide solution (Johnson Mathey Ltd) for $1 \mathrm{~h}$ at $4^{\circ} \mathrm{C}$, dehydrated in ethanol and embedded in Araldite (Ciba, Ltd). Ultrathin sections were cut on an ultratome (LKB Instruments, Croydon) and examined without any further staining in a Philips EM300 or EM 301 electron microscope. Controls consisted of a portion of the test pus treated with peroxidase-conjugated normal rabbit serum. To ensure that the results obtained were not due to any endogenous peroxidase activity of the sample, relevant portions were treated with acid ethanol $(2 \mathrm{ml}$ of concentrated $\mathrm{HCl}$ in $100 \mathrm{ml}$ of absolute ethanol) before and after application of the conjugated serum.

Reaction with 125 I antibodies. Three labelled sera were used, namely (1) human serum from a patient with septicaemia (StG 127), (2) rabbit anti-human phagocyte serum, and (3) rabbit anti-T $T_{2}$ gonococcal serum. The antigens, a pool of human pus from 14 patients with acute gonorrhoea, human peripheral phagocytes isolated by the method of Rabinowitz (1964), and $\mathrm{T}_{2}$ colonies of $N$. gonorrhoeae from GC agar, were fixed in a mixture of glutaraldehyde and PBS for $24 \mathrm{~h}$ at $4^{\circ} \mathrm{C}$ and washed twice with 200 times the volume of PBSH. In the reaction mixtures, approximately $0.05 \mathrm{ml}$ of the appropriate antigen pellet was resuspended in $1 \mathrm{ml}$ PBSH, mixed with serum globulin (c. 1.5 $\times 10^{6}$ c.p.m.) and incubated overnight at $4^{\circ} \mathrm{C}$. Next day the mixtures were centrifuged, the sediments washed thrice with 
PBSH and the radioactivity was measured in the fractions so obtained. Anti-gonococcus sera (from patients with septicaemia or from rabbits) reacted with gonococci from cultures and with pus samples, but did not react with the human peripheral phagocyte suspension (less than $0.3 \%$ radioactivity bound to phagocytes as compared with c. $20 \%$ bound to the pus and gonococcal samples). Anti-human phagocyte serum did not react with gonococci but did with the pus and the human peripheral phagocytes samples.

The final sediments were post-fixed in glutaraldehyde-acrolein and embedded and sectioned as above.

\section{Autoradiography}

Ultrathin sections on 200-mesh Formvar-coated grids were attached to glass slides which were then evenly coated with a preformed gel layer of Ilford L4 photographic emulsion applied with a loop (Pelc, Coombes and Budd, 1961; Caro, van Tubergen and Kolb, 1962). The slides were incubated with a drying agent for 14-21 days at $4^{\circ} \mathrm{C}$, and then developed with Kodak Microdol X for $3 \mathrm{~min}$., fixed in acid fixative for $7 \mathrm{~min}$. and washed in water for $30 \mathrm{~min}$. The grids were then treated with $0.1 \mathrm{~N} \mathrm{NaOH}$ for $5 \mathrm{~min}$. and stained with Reynolds lead citrate for $4 \mathrm{~min}$.

\section{RESULTS}

\section{Infectious units}

We have defined an infectious unit as a cluster of multiplying gonococci surrounded by granules and remnants of phagocytic cells (Novotny, Short and Walker, 1975). This definition was based on the observation of replicas and sections of several pus samples. In the present study more than 70 pus samples from patients with gonorrhoea were thoroughly examined; most were from males and only 20 from females. Most of the samples were examined individually, but in a few cases in which only a small amount of pus was available the samples were pooled. All the specimens were investigated by ultrathin sectioning and in the majority of cases serial sections were made. Our observations are summarised as follows.

The number of single gonococci without a coating of granules was variable. When present, these cocci were usually intracellular or close to phagocytic cells in the process of phagocytosis. It was common to find a morphological change in these organisms, some appearing well preserved and others in various stages of degradation; no evidence of their multiplication was found.

In the majority of cases examined, gonococci commonly occurred in infectious units, i.e., coated with vesicles. When only a few organisms were observed in section, the serial sectioning usually revealed that they were actually on the edge of a larger infectious unit sometimes made up of several hundred cocci surrounded by a more or less dense matrix of vesicles (figs. 1-4, 7 and 10). The overwhelming majority of gonococci in pus from either men or women appeared therefore to be present in the form of infectious units, which very often appeared in close contact with urethral epithelial cells.

Serial sections showed that the infectious units still held the shape of the cells in which they were formed; around each cluster of cocci was the partially preserved remnant of the phagocyte membrane. Detection of this membrane was much easier in replicas (Novotny, Short and Walker, 1975) and it seemed that this membrane and the phagosome membrane were the first structures to 
be destroyed. Very often the infectious unit included the remnant of a nucleus which was round or nearly round (figs. 1, 2 and 10) and between the great variety of morphologically heterogeneous vesicular structures were also seen remnants resembling mitochondria (fig. 4), these structures being characteristic of macrophages (Cohn and Wiener, 1963; Baggiolony, Hirsch and DeDuve, 1970). It is important to note, however, that the infectious units in pus consisted almost exclusively of host cells in a high degree of disorganisation and that it was sometimes impossible to determine the exact origin of the cell, although all infectious units generally looked remarkably similar.

In some infected leucocytes the granules surrounding the gonococci were some distance away and in such cases a fuzzy coat could be seen on the periphery of the gonococci (fig. 6), but this was an exceptional observation. In order to determine the origin of this granular coating in infectious units the techniques of high resolution autoradiography and peroxidase immunohistochemistry were used. The rabbit antigonococcal $T_{2}$ or $T_{4}$ antiserum used in these experiments reacted normally with the gonococcal surface and L-layer blebs (derived from the outer cell-wall membrane) by giving a heavy deposit of antibodies when observed by immune electron microscopy (Novotny and Turner, 1975). Similar reactions were observed when sera from patients with gonococcal septicaemia were used (figs. 18 and 19).

The antigonococcal $T_{2}$ serum coupled to horseradish peroxidase, although rich in antibodies directed against the gonococcal surface, did not react with gonococci in infectious units when they were heavily coated with vesicles (fig. 10). The serum showed a positive reaction in the form of patches on some rather amorphous matter (? fuzzy coat) and some of the vesicles (fig. 11). However, when gonococci were without a coating or were surrounded with small amorphous granules, a very heavy label was observed on the gonococcal surface as well as on these amorphous masses (fig. 12). There was usually also a delicate label on areas of some polymorph and epithelial cell surfaces (fig. 11). It appeared therefore that the coating of gonococcal clusters by densely packed large vesicles prevented the penetration of labelled antibody. When this was absent or disappearing, labelling of gonococci occurred. There was no difference in the label when $T_{4}$ antiserum was used instead of $T_{2}$.

Serum from the septicaemic patient similarly labelled the gonococcal surface and some vesicles. The majority of vesicles, however, remained unlabelled. Patches of stain could also be found on polymorphs and epithelial cells.

When anti-human phagocyte serum labelled with 125I was used in autoradiography experiments, a deposit of reduced silver particles was seen on granules surrounding the cocci (fig. 7). Anti-gonococcal $T_{2}$ serum, similarly labelled, formed deposits on clusters of cocci. However, the resolution of the technique was not sufficient to establish the location of radioactive seroaggregates.

It was more convenient to use anti-human polymorph serum labelled with horseradish peroxidase and this labelled the gonococcal surface (figs. 8 and 9) and most of the vesicles very heavily. It also labelled the surfaces of poly- 
morphs, epithelial cells and erythrocytes, but did not label free gonococci in pus that were not surrounded by the granular coat. It therefore appeared that human antigenic material was closely adjacent to the surfaces of gonococci. Control peroxidase-labelled sera from normal rabbits did not specifically label any structures in sections. Endogenous peroxidase activity present in the specimens was controlled by the use of acid ethanol.

We have not seen any polymorph in the process of phagocytosing gonococci in infectious units when there was a heavy granular coating; however, when the gonococci had partially or completely lost their granular coats, they appeared to be immediately phagocytosed.

The majority of infectious units were in close contact with an epithelial cell. Very often the latter showed degenerative changes such as loss of internal structure and stainability and this change could be seen without any evidence of invasion. Very rarely the infectious unit as a whole complex could be seen partially inside the epithelial cell (fig. 5). On occasion, in samples from the cervix, large epithelial cells with villi were present, but no marked affinity between these epithelial cells and the infectious units was apparent. Pili were seldom seen associated with gonococci in pus. The infectious units were evidently anchored to epithelial cells in such a way that the granules were seen partially inserted in them (figs. 1,2 and 8). Very often the plasma membrane of the epithelial cell under the infectious unit could not be detected (fig. 2).

The liberation of surface structures in the form of blebs and bizarre appendages from gonococci appeared to be normal at any phase of growth in vitro. When freshly formed, these blebs are serologically very active and have a characteristic appearance; they were not observed under natural conditions.

The damage to gonococci inside polymorphs starts with changes in the cytoplasm. The surface layers during these stages remained parallel although weakening of their structural integrity was often apparent.

\section{Experiments with chambers in guinea-pigs}

Characteristics of chronically infected chambers. When guinea-pig chambers were infected with virulent strains of $N$. gonorrhoeae, infection was detectable for 2-6 months (Turner and Novotny, 1976). After an early maximum of $10^{8}-10^{9}$ c.f.u. per $\mathrm{ml}$ appearing $2-7$ days after the infection, the number of c.f.u. decreased to a level of $10^{5}-10^{6}$ and was detectable with small variations throughout the whole period of infection until spontaneous disappearance. This behaviour, observed with many strains, was also valid for the strain Pat 1 used in this study. An infected chamber usually contained pus cells, but the bacterial counts were low; one could only rarely see free gonococci or phagocytosed gonococci in the smears of the exudate. In order to ascertain whether the phagocytes inside the chamber were able to ingest gonococci, $1 \mathrm{ml}$ of a saline suspension of $\mathrm{T}_{2}$ gonococci ( $10^{10}$ c.f.u.) from a $\mathrm{GC}$ plate was injected into an already infected chamber and samples were taken at appropriate intervals. Within 3-4 h, gonococci were morphologically undetectable in the smear. In samples taken $80 \mathrm{~min}$. after the injection it was evident that the 
gonococci were being rapidly killed (fig. 15) without phagocytosis. Only very rarely was it possible to find even one or two phagocytosed gonococci in a polymorph (fig. 16). Even before such superinfection, the majority of polymorphs contained large dense granules or vacuoles or both and appeared nonfunctional. They were reminiscent of human "toxic polymorphs" (Quie, 1975). The guinea-pigs superinfected with these large doses of gonococci often died overnight-evidently by the Herxheimer effect, i.e., by a sudden release of endotoxin from the rapidly lysed cocci. No generalised infection was observed in any of the normal or superinfected guinea-pigs. The rapid death of gonococci inside the chronically infected and superinfected chambers is mysterious. However, the gonococci in the chamber were similar in appearance to gonococci inside phagosomes, i.e., the first signs of destruction were a decrease in the stainability of the cytoplasm, and coagulation, to be followed later by disappearance, of the nucleoplasm. The cell-wall layers appeared rather resistant to lysis and again no release of the surface structures in the form of blebs was observed, in contrast to the lysis of gonococci kept under artificial conditions. The concentration of complement in the chamber exudate was very low even in uninfected chambers. The usual titre determined was $2-4$ as compared with a mean titre of 200 in the circulating blood of the same animals. When a high titre of anti-pilar antibody was detected by immune electron microscopy in the guinea-pig serum, the supernate of the chamber exudate contained similar antibodies. However, even when guinea-pig complement was added, the chamber liquid was not demonstrably bactericidal and, in in-vitro experiments with cell-free exudate, this fluid quite often appears to be only bacteristatic (Dr C. Penn, Department of Microbiology, Birmingham University, personal communication).

The redox potentials in four infected chambers were +200 to $+286 \mathrm{mV}$ (corrected for a hydrogen electrode at $38^{\circ} \mathrm{C}$ ) and the values were similar in two chambers in which the infection had died out. These values were generally higher than those determined when the electrodes were inserted into the hearts of narcotised animals, where values of +120 to $+230 \mathrm{mV}$ were found. Certainly, such high values in the chamber liquid are not comparable with values obtained in extravasated blood in which a drop in redox potential occurs very rapidly (see Smith, 1949).

The lysozyme content in the chamber liquid was rather high-in the region of 190 units per $\mathrm{ml}$ (measured on two pools of exudate, one from 20, the second from 180 chambers). Acid and alkaline phosphatases were present in the chamber liquid. Mean values for alkaline phosphatase of $5.3 \mu$.moles per min. per $\mathrm{ml}$ and for acid phosphatase $16 \mu$.moles per min. per $\mathrm{ml}$ were measured with the pools mentioned above.

From the morphological appearance of the cocci, the relatively high redox potentials and the presence of the enzymes, we assume that the chamber liquid was in some ways similar in composition to the contents of a phagosome.

On histological examination, the uninfected capsules were found to be embedded in fibrous tissue, with small buds of fibroblasts protruding through the holes into the chamber. Eventually, if the holes in the capsule were too 

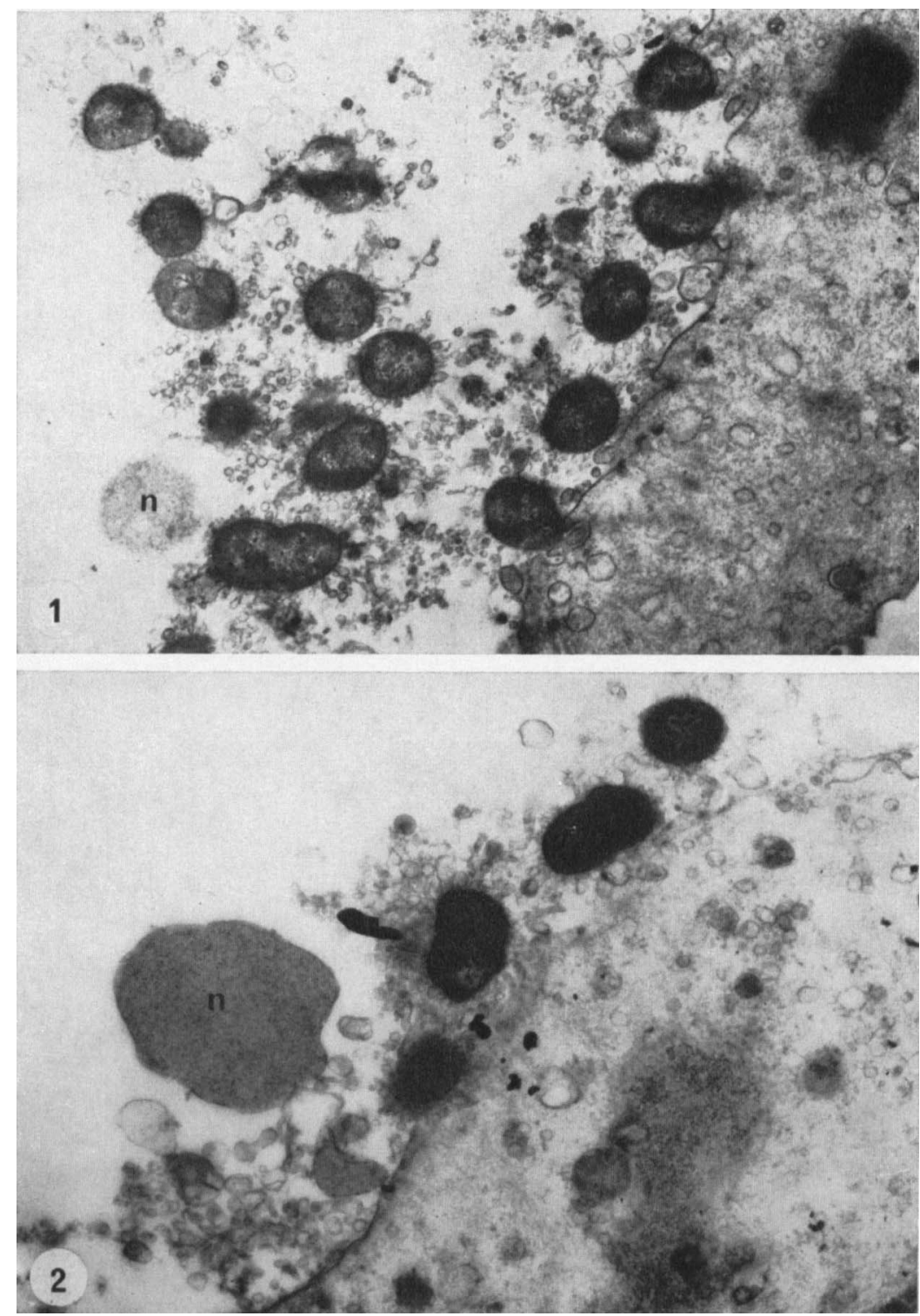

Frg. 1.-Thin section through a large infectious unit on an epithelial cell. Pus sample taken from a man with acute gonorrhoea. Note a remnant of a barely stainable nucleus (n) derived from the host cell in which the gonococcal cluster was borne. Electronmicrograph. $\times 17000$.

FIG. 2.-Thin section through a small infectious unit on an epithelial cell. Pus sample from a man with acute gonorrhoea. The nuclear membrane on the nucleus $(n)$ of the host cell is still visible. EM. $\times 17000$. 


\section{Pathogenicity of N. GONORRHOEAE}
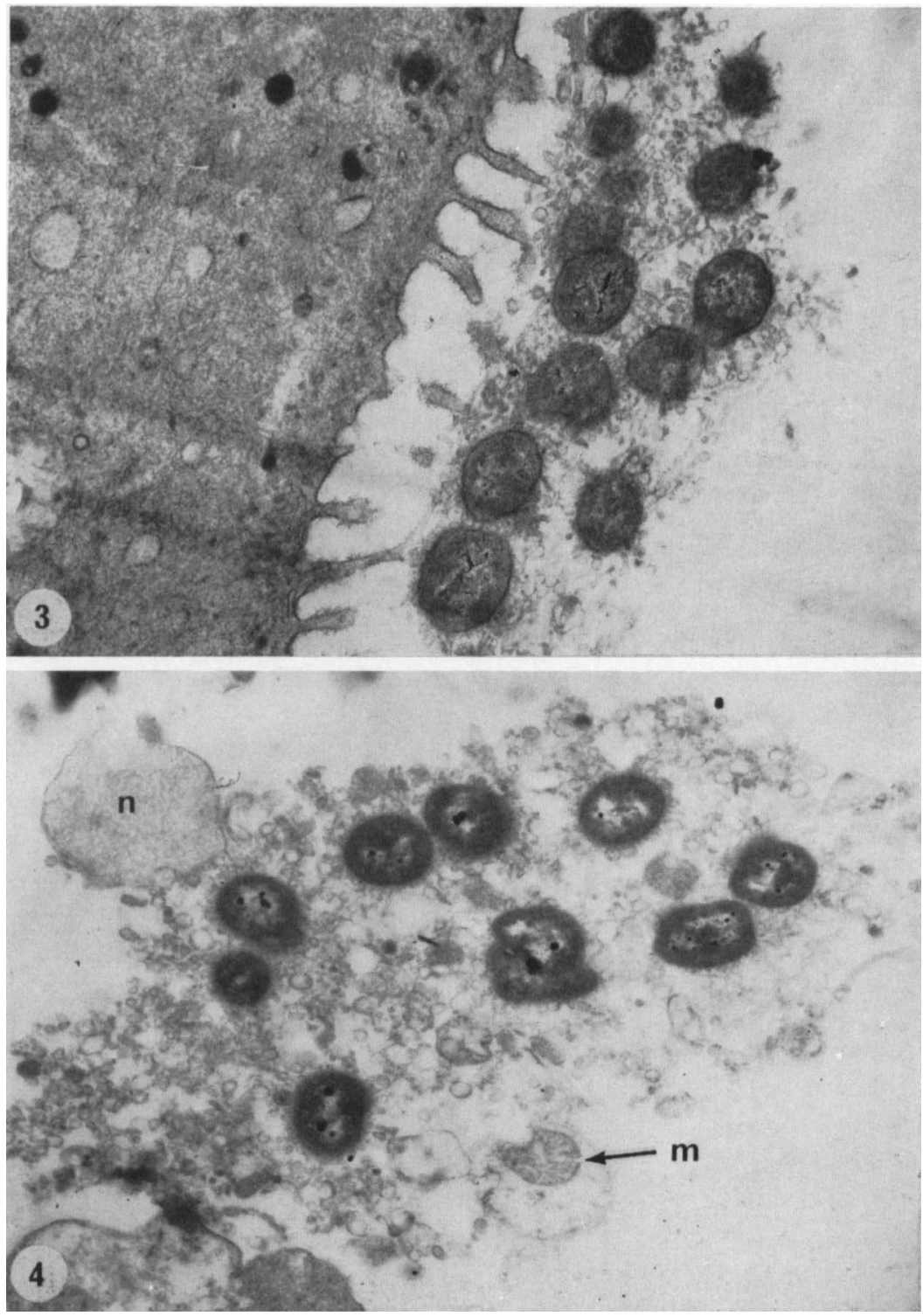

FIG. 3.-Thin section of an infectious unit adhering to the villi of an epithelial cell. EM. $\times 20400$.

FIG. 4.-Thin section of an infectious unit showing nuclear remnants (n) and the remnants of a mitochondrion (m). EM. $\times 17000$. 
PAthogenicity OF N. GONORRHOEAE
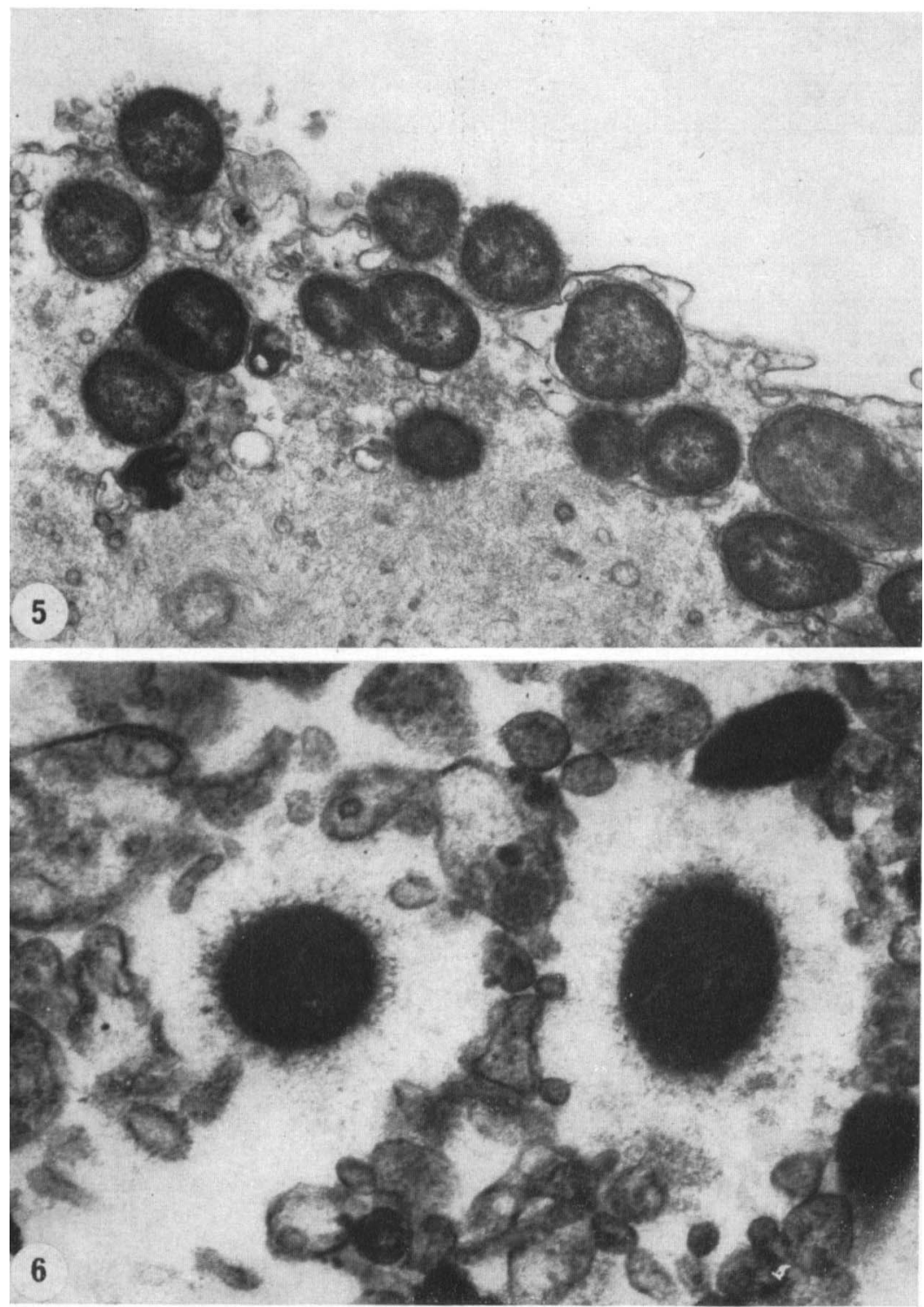

FIG. 5.- Thin section of pus from acute gonorrhoea in a woman (cervix). An infectious unit is partially inside the epithelial cell. Many gonococci in this cluster are still coated with granules. EM. $\times 21250$.

FIG. 6.- Thin section of human pus from a patient with acute gonorrhoea. Gonococci with a fuzzy coat surrounded by organelles. EM, $\times 69360$. 


\section{PATHOGENICITY OF $N$. GONORRHOEAE}
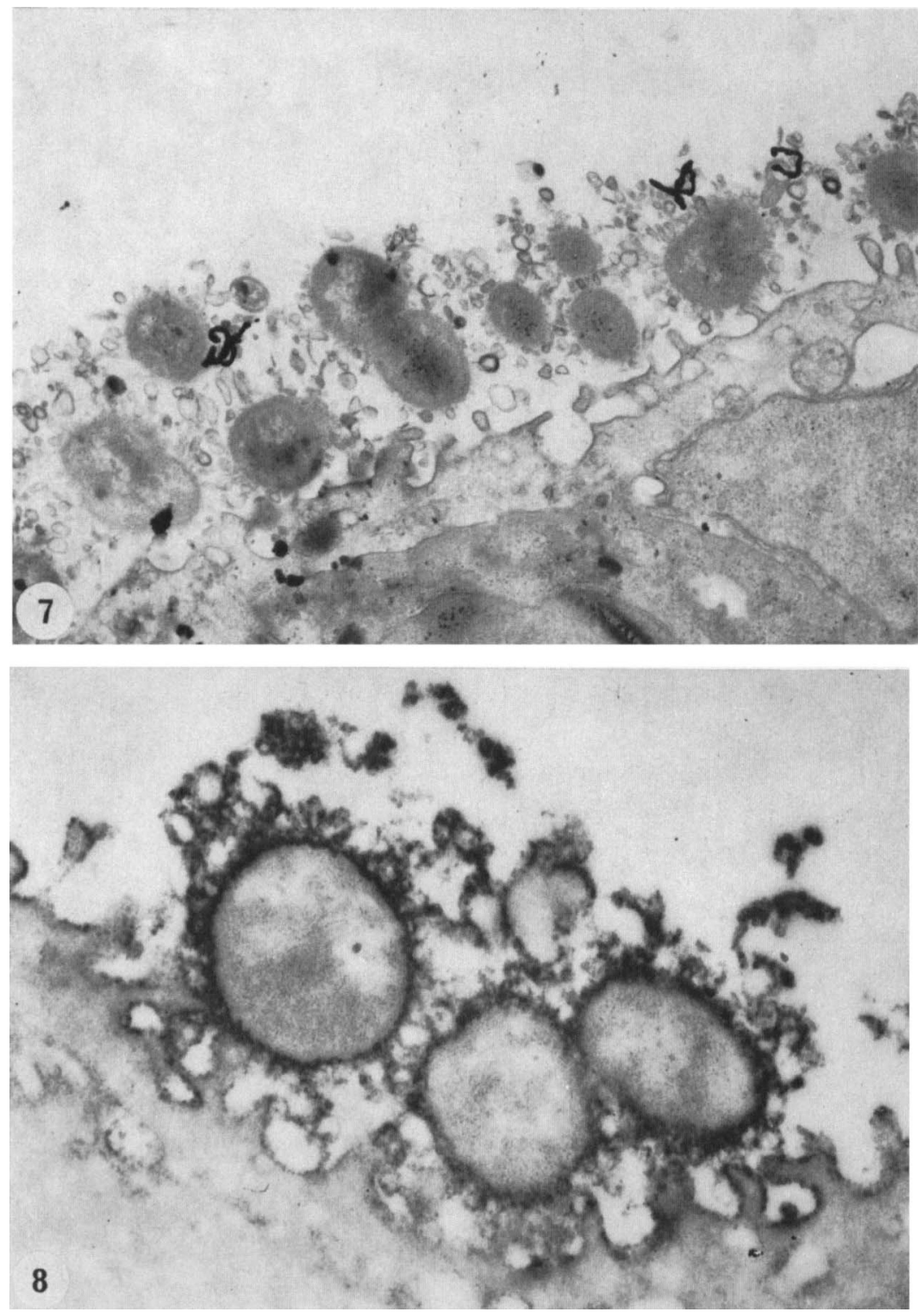

FIG. 7.-Autoradiography of thin section of human pus from patients with gonorrhoea after treatment with 125 I-labelled rabbit anti-human phagocyte serum. The label was localised in the coat of clusters as well as on epithelial cells and phagocytes. EM. $\times 21250$.

FIG. 8.-Thin section of pus from patients with acute gonorrhoea. The pus sample was treated with rabbit anti-human phagocyte serum labelled with horseradish peroxidase. A heavy peroxidase label appears around the cocci as well as on the surface of the epithelial cell. The concealment of the identity of the gonococci by organelles of human origin appears to be complete. EM. $\times 34000$. 

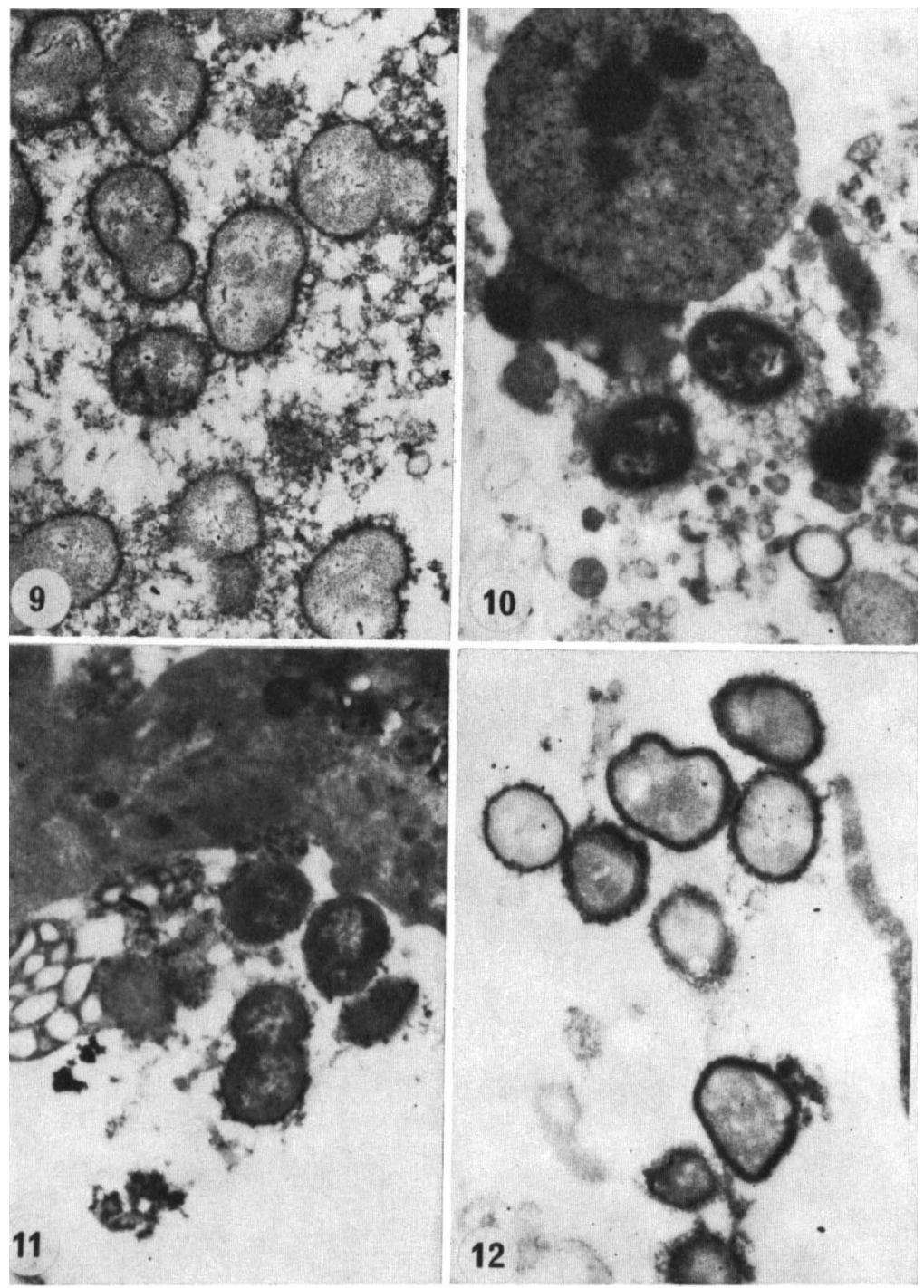

FIG. 9.- Thin section of pus labelled with anti-human phagocyte serum as in fig. 8. Part of an infectious unit adheres to an epithelial cell. EM. $\times 17000$.

Fig. 10.-Thin section of human pus. Although treated with anti-gonococcus $\left(\mathrm{T}_{2}\right)$ rabbit serum labelled with horseradish peroxidase, no staining of the gonococcal wall is evident. The cocci appear to be densely surrounded by granules and are closely associated with the host-cell nucleus. EM. $\times 20400$.

Fig. 11.-Thin section of human pus after treatment with anti-gonococcal $\left(\mathrm{T}_{2}\right)$ rabbit serum labelled with horseradish peroxidase. Inside the clusters the reaction with the gonococcal surface was rather weak or negative. EM. $\times 15937$.

Fig. 12.-Thin section of pus after treatment with anti-gonococcal $\left(T_{2}\right)$ rabbit serum labelled with horseradish peroxidase. In clusters of cocci sparsely coated with organelles or completely devoid of these, the reaction with the gonococcal surface was strongly positive. EM. $\times 21250$. 

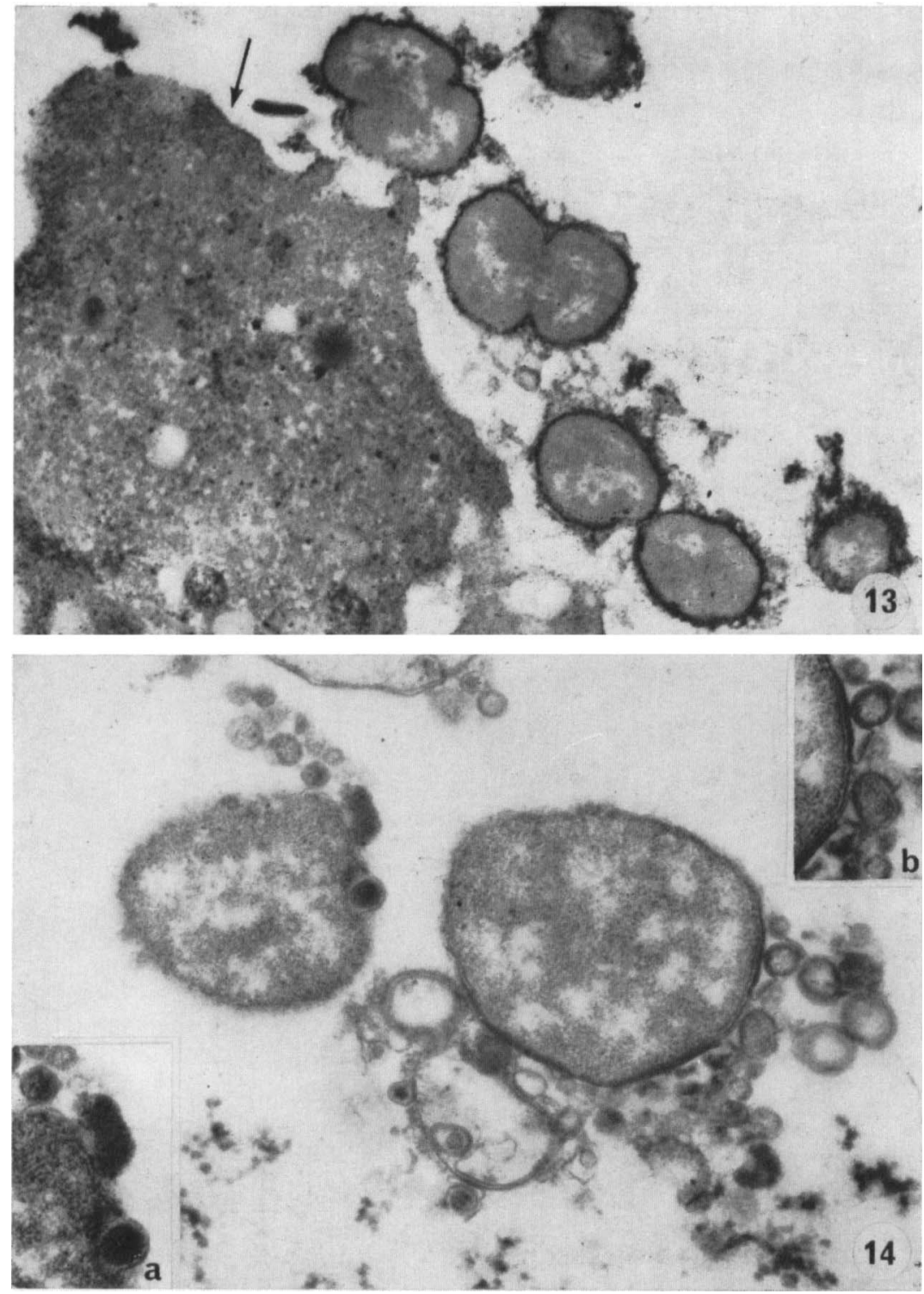

FIG. 13.-Thin section of human pus after treatment with human serum labelled with horseradish peroxidase. The serum originated from a patient with gonococcal septicaemia (StG 127). The peroxidase label appears on the surface of gonococci and on patches of granular coat. A soluble gonococcal antigen is probably formed. EM. $\times 21250$.

FIG. 14.-Thin section of pus from peritoneal exudate of a mouse that received an injection of a culture of gonococci and colchicine. Some lysing cocci appear to be releasing mesosome-like vesicles. $\times 32000$. Inset a: The mesosome-like vesicle appears to be localised between the plasma membrane and the cell wall. EM. $\times \mathbf{4 0} 800$. Inset $\mathrm{b}$ : The outer cell wall layer is ruptured and mesosome-like vesicles have been released. EM. $\times 40800$. 

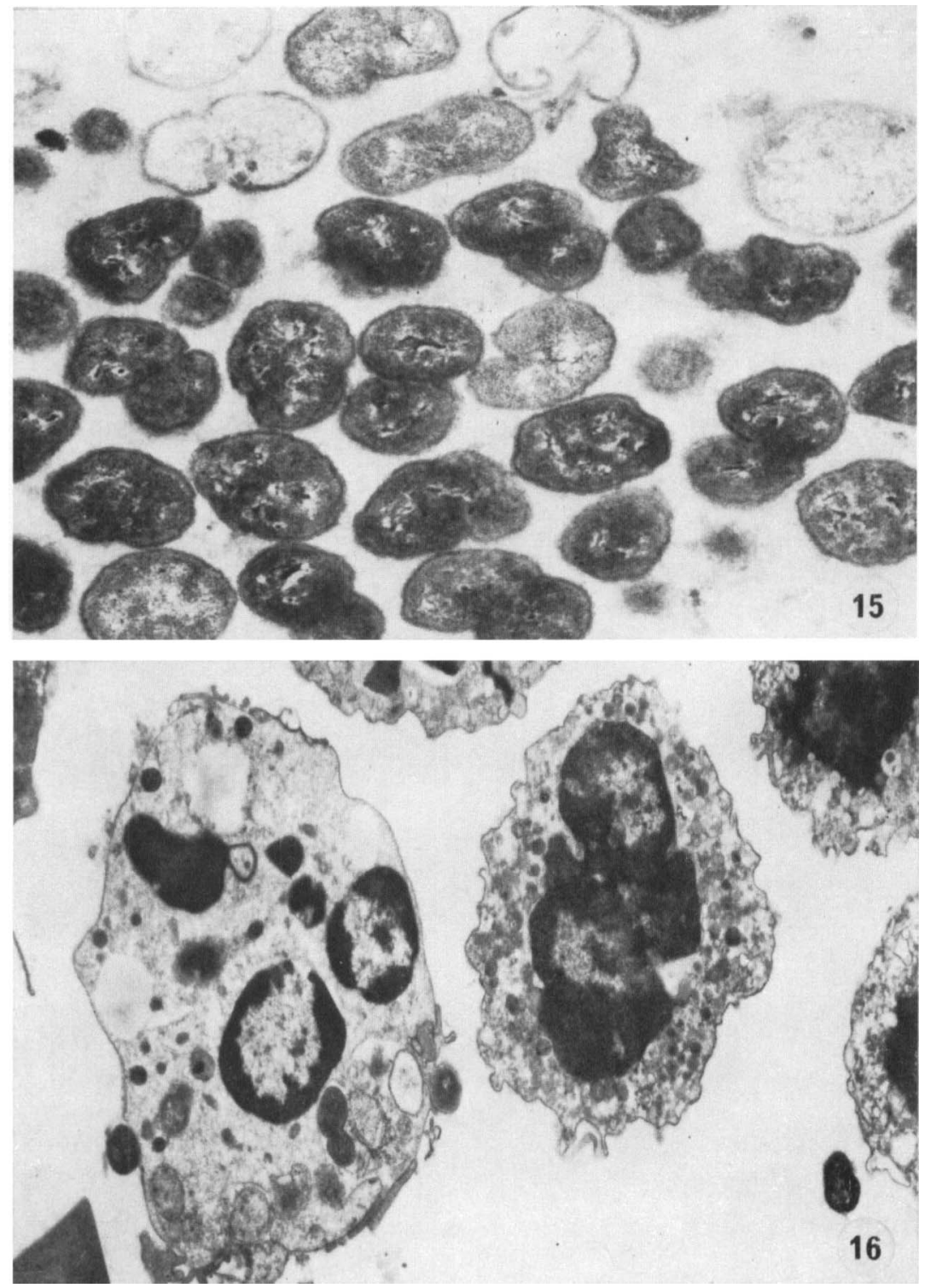

FIG. 15.-Thin section of exudate $80 \mathrm{~min}$. after the injection of a large dose of gonococci into an already infected guinea-pig chamber. Note (i) the destruction of some of the gonococci without phagocytosis, and (ii) the relatively smooth surface of the gonococci without liberation of Llayer blebs although the cocci originated from a plate of GC medium. EM. $\times 26562$.

FIG. 16.--A thin section demonstrating an apparently rare event inside the guinea-pig chamber: the gonococci are seen to be phagocytosed or in the process of being phagocytosed. The majority of phagocytes in the infected chamber contents generally contained granules and vacuoles and appeared non-functional. EM. $\times 8670$. 

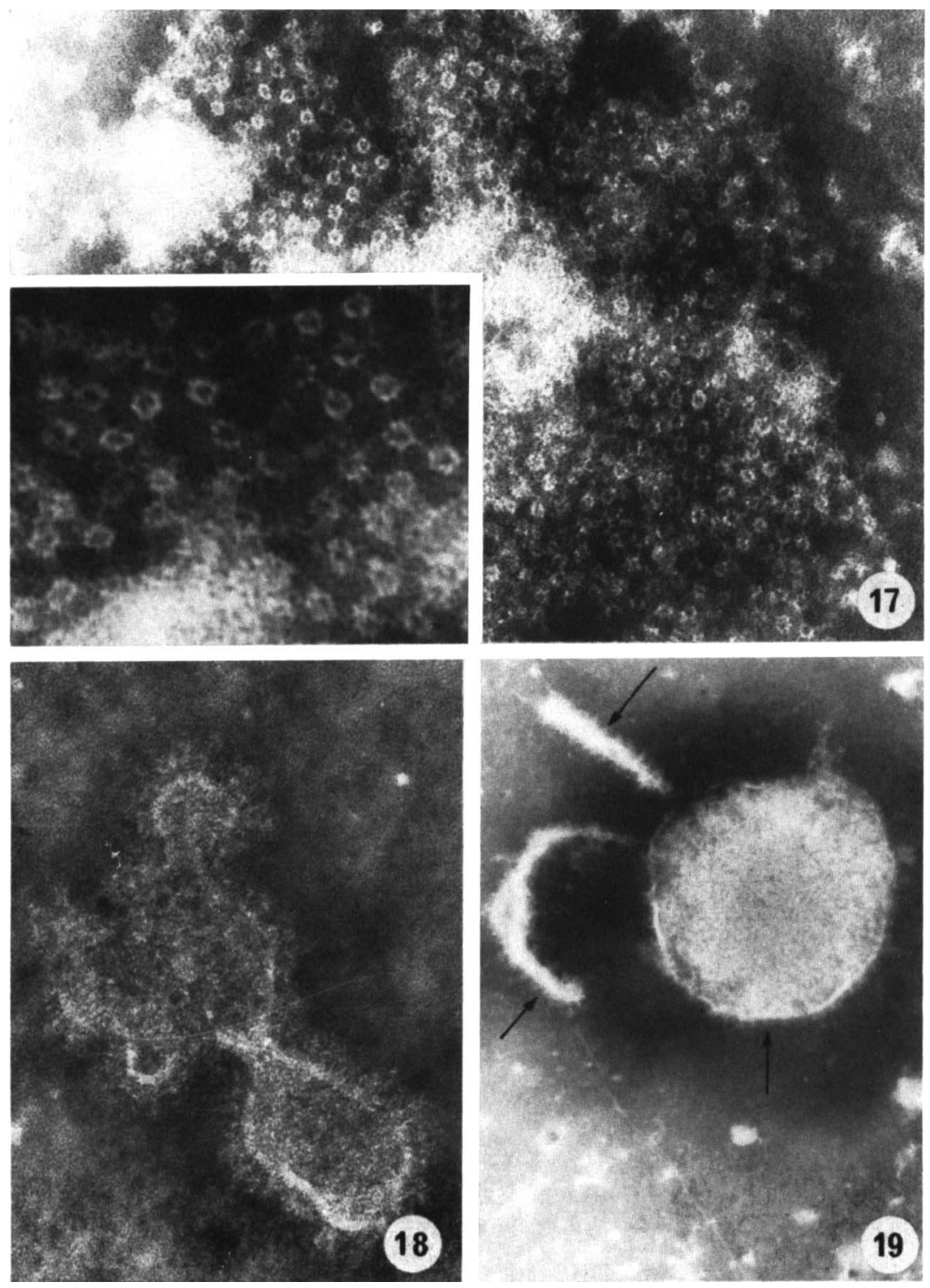

FIG. 17.-A negatively stained preparation of free ring structures liberated from the L-layer of gonococci by autolysis and agglutinated by a serum of a patient (StG 176) suffering from gonococcal septicaemia. Note the combining IgG molecules. EM. $\times 187000$. Inset: A magnification of the same specimen. EM. $\times 561000$.

FIG. 18.-Immune electron microscopy with a serum of a patient with gonococcal septicaemia (StG 58 ) and the corresponding GC agar cultured strain of $N$. gonorrhoeae (StG 47). A bleb derived from the surface layer of the gonococci is coated with combining antibodies. Negative stain. EM. $\times 187000$.

FIG. 19.--Immune electron microscopy with the serum of a patient with gonococcal septicaemia (StG 176) applied to the corresponding strain of N. gonorrhoeae (StG 176C) cultured in embryonated eggs. The whole surface of the coccus as well as the liberated surface layer in the form of long appendages is coated with combining antibodies (arrows), whereas no antibodies can be seen on the pilus. This result was typical with all the sera obtained from patients with septicaemia except on one occasion with the above serum and the isolate StG 176U. Negative stain. EM. $\times 70125$. 


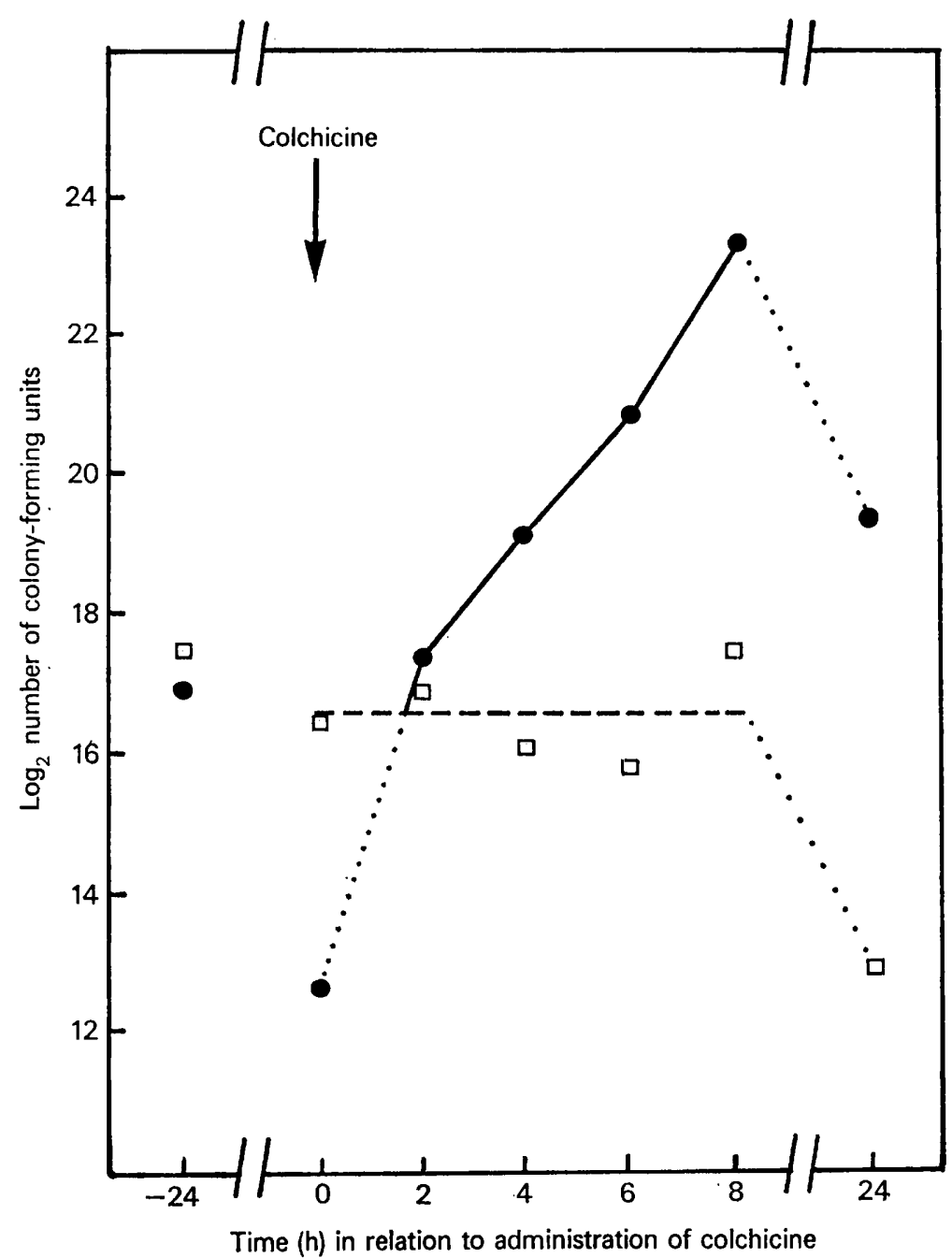

FIG. 20.-The effect of injecting $5 \mu$.moles of colchicine into an Arko's chamber chronically infected with $N$. gonorrhoeae strain Pat 1 . A control infected chamber received an injection of sterile saline. The number of viable gonococci is expressed as the number of colony-forming units obtained from samples of the chamber content taken at the times indicated.

Colchicine test; $\square=$ control data;..$--=$ average of the control counts for the $8-h$ test period.

large these fibroblasts buds sometimes filled the chamber interior. In infected chambers a demarcation by reactive inflammation occurred and the fibrous tissue was heavily infiltrated with pus cells forming a layer about $2 \mathrm{~mm}$ thick. Occasionally in this layer it was possible to find pairs of gonococci, but only after many fields in the section had been examined. There was no evidence of the formation of infectious units in the surrounding tissues. It is important to stress that liquefaction of the surrounding tissues never occurred in capsules infected with gonococci; to remove the infected capsule, it was necessary to 
pull it out with some force after the incision of the skin. Liquefaction was, however, normal and very prompt when the chamber became contaminated with other bacteria such as staphylococci, Escherichia coli, or other Gramnegative rods. It was clear that the gonococci were leukotaxic, but activation of granules in the inflammatory cells to produce liquefaction and rejection of the infected foreign body was either not induced or was inhibited.

Influence of colchicine. From the observations on human pus it was concluded that the internal regulation of phagocytes was disordered. In experiments with guinea-pigs it became evident that gonococci were unable to survive long inside the chamber cavity. The constant concentration found during the whole period of infection may reflect an equilibrium between steady multiplication and death. If so, then colchicine-which interferes with the cellular regulation but has little effect on phagocytosis (Malawista and Bodel, 1967; Pesanti and Axline, 1975)—should be able to disrupt this chronic equilibrium. This prediction was confirmed.

In these experiments, guinea-pigs had two implanted chambers, both of which were infected with the same gonococcal strain 4-6 weeks before the drug test. One chamber served as a control and received an injection of saline. At the same time the second chamber received the same volume of saline $(0.2 \mathrm{ml})$ containing $5 \mathrm{~m}$.moles of colchicine. The exudates from both chambers were sampled at intervals and colony counts performed. In the exudate from the colchicine chamber the number of c.f.u. increased 100 times within $8 \mathrm{~h}$ (fig. 20). The slope of the increase was similar in all guinea-pigs tested; the final concentration differed according to the initial concentration of bacteria. The doubling time for the increase of gonococci in the chamber liquid was approximately $60 \mathrm{~min}$. This apparent growth rate most probably also reflects death as well as multiplication of gonococci and, therefore, the actual growth rate may have been higher. After $24-40 \mathrm{~h}$, the number of gonococci decreased to the starting level. There was no increase in the number of gonococci in the exudate of the second, control chamber. Some guinea-pigs died the day after the colchicine experiments. There was no generalised infection; death was probably due to the liberation of endotoxin associated with lysis of the suddenly increased numbers of gonococci. Death was not due to colchicine because the same quantity injected into the chambers of non-infected guinea-pigs was not lethal.

All guinea-pigs in the colchicine series had oedematous tissue surrounding the chamber 20-24 $\mathrm{h}$ after the experiment. On section, the tissue was gelatinous and a very distinct yellow layer of pus cells surrounded the gelatinous infiltrate. This inflammation usually subsided within 3-4 days and again no liquefaction of the tissue occurred. Around the colchicine chamber some guinea-pigs developed dry gangrene several days after the experiment. In other guineapigs the colchicine chamber had the same appearance as before the experiment.

Colchicine did not have any influence on the growth of gonococci in vitro; colonies of gonococci grown for $20 \mathrm{~h}$ in the presence of up to $25 \mu \mathrm{mol}$ of colchicine spread in the dark on half of a GC plate were similar in size and appearance to those grown on the untreated half. 
Vinblastine has many similar properties to colchicine, but it did not influence the numbers of c.f.u. in chambers infected with gonococci when injected at a similar dose level.

\section{Immune electron-microscopy studies}

As strain-specific antigens were expected, it was mandatory to use the strains with which the patients were infected. Unfortunately, no isolates from blood cultures were available from these patients and all isolates originated from the urethra, cervix or both.

Detection of antibodies to pili. We were normally unable to detect anti-pilar antibodies in sera tested against the patients' homologous strains, i.e., StG $127 \mathrm{U}, 127 \mathrm{C}, 128 \mathrm{U}, 128 \mathrm{C}$ and 47 , although acute-phase and convalescent-phase sera were tested several times with isolates from both cervix and urethra. It was therefore presumed that antibodies to pili are not usually formed in human beings, even in those with gonococcal septicaemia. After many negative results, serum StG 176 was found on one occasion to label some pili present in an isolate from the urethra, but not from the cervix.

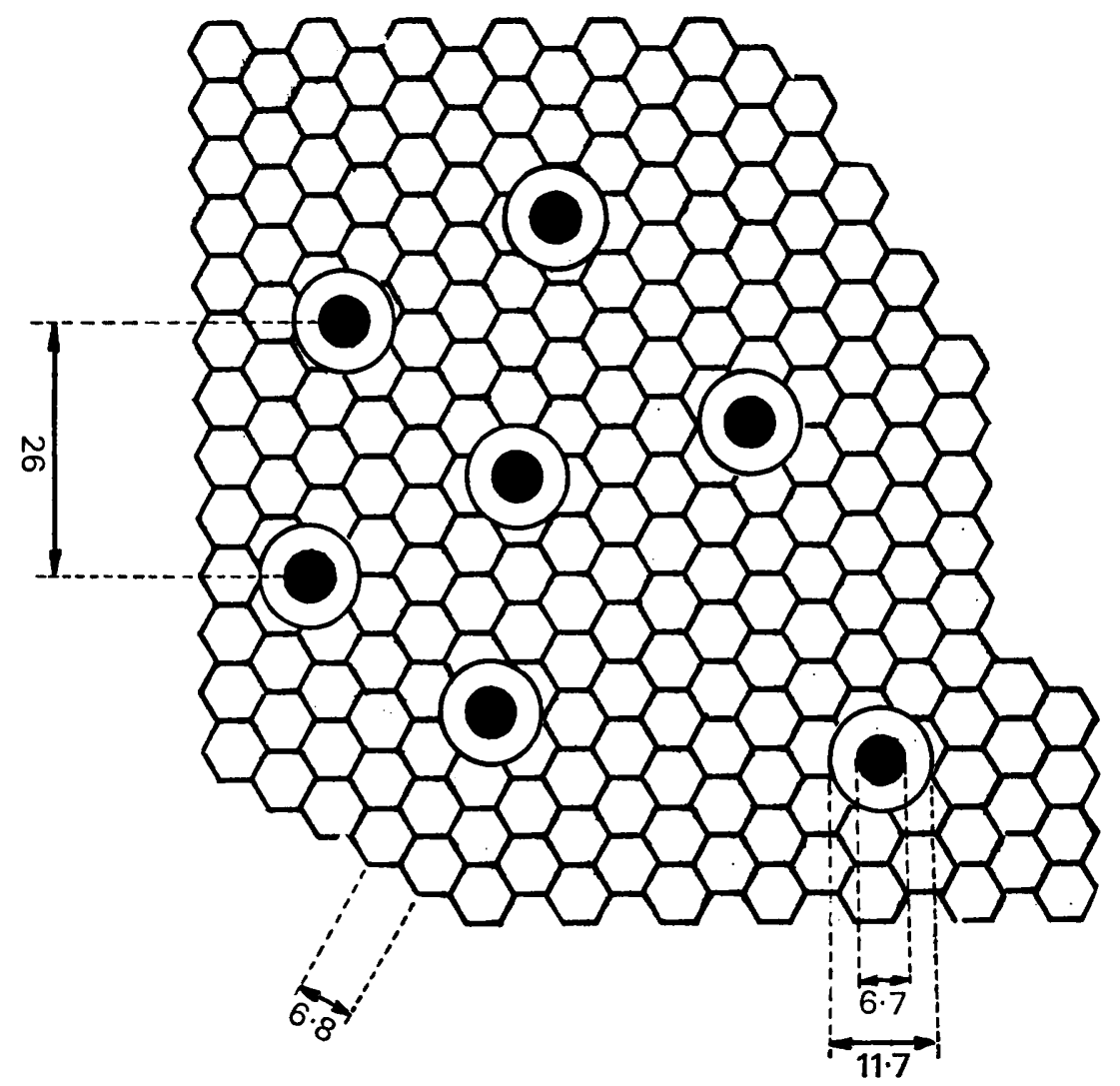

FIG. 21.-A provisional diagram based on electron micrographs (Novotny, Short and Walker, 1975) of Neisseria gonorrhoeae $\mathrm{T}_{1}$ and $\mathrm{T}_{2}$ endotoxin " backbone" (see text for explanation). Mean measurements expressed in $\mathrm{nm}$. 
Detection of antibodies against free endotoxin. Two kinds of free endotoxin particle derived from the L-layer (i.e., the outer cell membrane) of the cell wall are to be found in gonococcal cultures (Novotny, Short and Walker, 1975), namely particles with no visible fine structure, coated particles, and those whose fine structure is visible, naked particles; these particles reacted differently in serological tests (Novotny and Turner, 1975).

Coated particles are usually heavily labelled with IgG when mixed with either rabbit or guinea-pig immune serum, or sera obtained from septicaemic patients (figs. 18 and 19). However, when immune electron microscopy was used for the detection of antibodies in sera from patients it was necessary to use only freshly prepared suspensions of gonococci and even then not all the blebs present in the specimen were labelled with antibodies. When bacterial suspensions kept for 2-3 days at $4^{\circ} \mathrm{C}$ were used, the particles usually all gave negative results. It appears, therefore, that the superficial antigen coating the L-layer which reacts heavily with human septicaemic serum is either labile or readily dissolved.

A diagram of the structure of a naked particle (fig. 21) shows ring structures (pits according to Swanson et al., 1971; Swanson, 1972) embedded in a basic hexagonal lattice of lipopolysaccharide(LPS). When these whole naked particles react with gonococcal antiserum, no binding antibodies are observed. However, in a culture lysate the ring structures are liberated from the LPS backbone. When a suspension of strain no. StG $176 \mathrm{C}$ harvested in the exponential phase of growth from the allantoic fluid of embryonated eggs was mixed with the corresponding patient's serum, these ring structures were agglutinated and formed large aggregates in which the binding IgG molecules were visible (fig. 17).

For all the above immune electron-microscopy reactions, we used cultured gonococci that were to a greater or lesser extent lysed. In all of the test mixtures, aggregates of IgG molecules were observed and this may indicate that gonococcal lysate contains soluble antigen(s) responsible for the aggregation of antibody molecules.

\section{Discussion}

Recent studies on the mechanism of gonococcal pathogenicity have paid attention to the in-vitro interaction of individual gonococci with human cells (Swanson, 1972; Punsalang and Sawyer, 1973; Swanson, 1973; Thongthai and Sawyer, 1973; Thomas, Hill and Tyeryar, 1973; Ward et al., 1974; Gibbs and Roberts, 1975; Swanson et al., 1975; Witt, Veale and Smith, 1976). The common approach in these studies was the comparison of results obtained with gonococci that were supposed to be virulent or avirulent, depending on their colonial morphology (Kellogg et al., 1963) and pilation (Jephcott et al., 1971; Swanson et al., 1971) so that the formula was: pilation $/ \mathrm{T}_{1}, \mathrm{~T}_{2}$ colonial forms $=$ virulent; non-pilation $/ T_{3}, T_{4}$ colonial form $=$ avirulent. Although there is some evidence that this broad separation is justified, its strict application is an oversimplification. This was shown for instance by Kellogg et al. (1968) who were able to infect human volunteers with $T_{3}, T_{4}$ colonial forms maintained in 
culture for up to 38 passages and by Arko et al. (1974) who found a $T_{2}$ organism non-virulent for chimpanzees. In our own studies, although the majority of virulent (i.e. $T_{1}, T_{2}$ ) gonococci, isolated from patients with uncomplicated acute gonorrhoea were able to infect, and survive in, Arko chambers in guinea-pigs (Arko, 1972 and 1974), this was not true of all strains obtained from patients with a generalised gonococcal infection. Laboratory criteria for the assessment of gonococcal virulence are therefore inadequate.

In our previous study (Novotny, Short and Walker, 1975) we found that cultured gonococci differed from naturally occurring cocci. In the course of the acute disease one might assume that all the multiplying gonococci present are virulent. It therefore seems important to know how and where this multiplication takes place, and to determine the relationship of multiplying gonococci to host cells.

It is well known from observations of routine diagnostic smears of pus from acute gonorrhoea that gonococci appear either phagocytosed or in clusters which are either free or more often in association with urethral epithelial cellsusually on their broad sides. It is useful to realise that columnar epithelial cells face each other with these broad sides. In other words, before desquamation took place, the gonococcal clusters were localised between the epithelial cells in the most superficial layer of the urethral mucosa. We have investigated these clusters further and our conclusions are as follows.

1. All the gonococci in a cluster, varying from a few to several hundred, are morphologically identical. Such cells occur only under steady-state conditions during exponential growth. We therefore conclude that the cells in clusters are multiplying cells.

2. All these gonococci in clusters are surrounded by granules. These were observed by other workers (Ovčinnikov and Delektorskij, 1971; Ward and Watt, 1972) but their origin was not explained. With high-resolution techniques of immunohistochemistry we have shown that the majority of the granules, if not all, contain human antigen. The identification of the origin of this in-vivo coating is important, for several types of particle are shed into culture media or can be detected in cell lysates from cultured gonococci in vitro. These include (i) pili and free endotoxin particles, both serologically reactive (Novotny, Short and Walker, 1975; Novotny and Turner, 1975), (ii) serologically reactive ring structures derived from the LPS backbone of free endotoxin (fig. 17), and (iii) mesosome-like vesicles which can be produced in large numbers (fig. 14) but are of unknown serological specificity. DeVoe (1976) reported the formation of typical L-layer vesicles during the in-vitro destruction of meningococci by phagocytes. This does not occur in vivo with gonococci during the early stages of destruction by pus cells; on the contrary the first changes appear in the cytoplasm (Novotny, Short and Walker, 1975). Amongst the particles we have observed surrounding gonococci in vivo are typical hostcell organelles like mitochondtia and a remnant of one host-cell nucleus, usually damaged, but present with an astonishing frequency (figs. 1,2 and 10). Serial sections revealed that an infectious unit rarely occurs without this host cell remnant. The typical appearance and constancy of the components of infectious units cannot be explained by a simple accumulation of cell debris from the pus.

It is therefore evident that infectious units are formed intracellularly and because of their uniform appearance a single source of origin or mother cell can be expected. Epithelial cells can be excluded for several reasons. Their nucleoplasm is considerably larger than that commonly associated with infectious units, the number of granules is limited and, finally, the membranes of epithelial cells persist in pus for a very long time, whereas in infectious units these are the first to disappear. We suppose, therefore, that the 
mother cell for infectious-unit formation is an actively phagocytic cell, and the presence of a great variety of granules and remnants of mitochondria seems to justify the suggestion that the mother cells are macrophages. We are, however, unable to present a total sequence of the formation of infectious units from the early stages of infection; to do this, it would probably be necessary to obtain specimens by curettage. We assume that the rapid destruction of the host cells is a result of rapid intracellular multiplication of cocci with the fast formation of infectious units. We conclude that free gonococci in pus surrounded by a granular coat have been derived from a macrophage.

We expect that the accumulation of granules around gonococci is a result of an active process. It is certainly not a simple physico-chemical absorption for, when pilate gonococci, harvested in the exponential growth phase from the allantoic cavity of embryonated eggs, were added to macrophages isolated from human blood by the method of Rabinowitz (1964) and disintegrated according to Depierre and Karnovsky (1973), no absorption of organelles or nuclei to gonococci was observed.

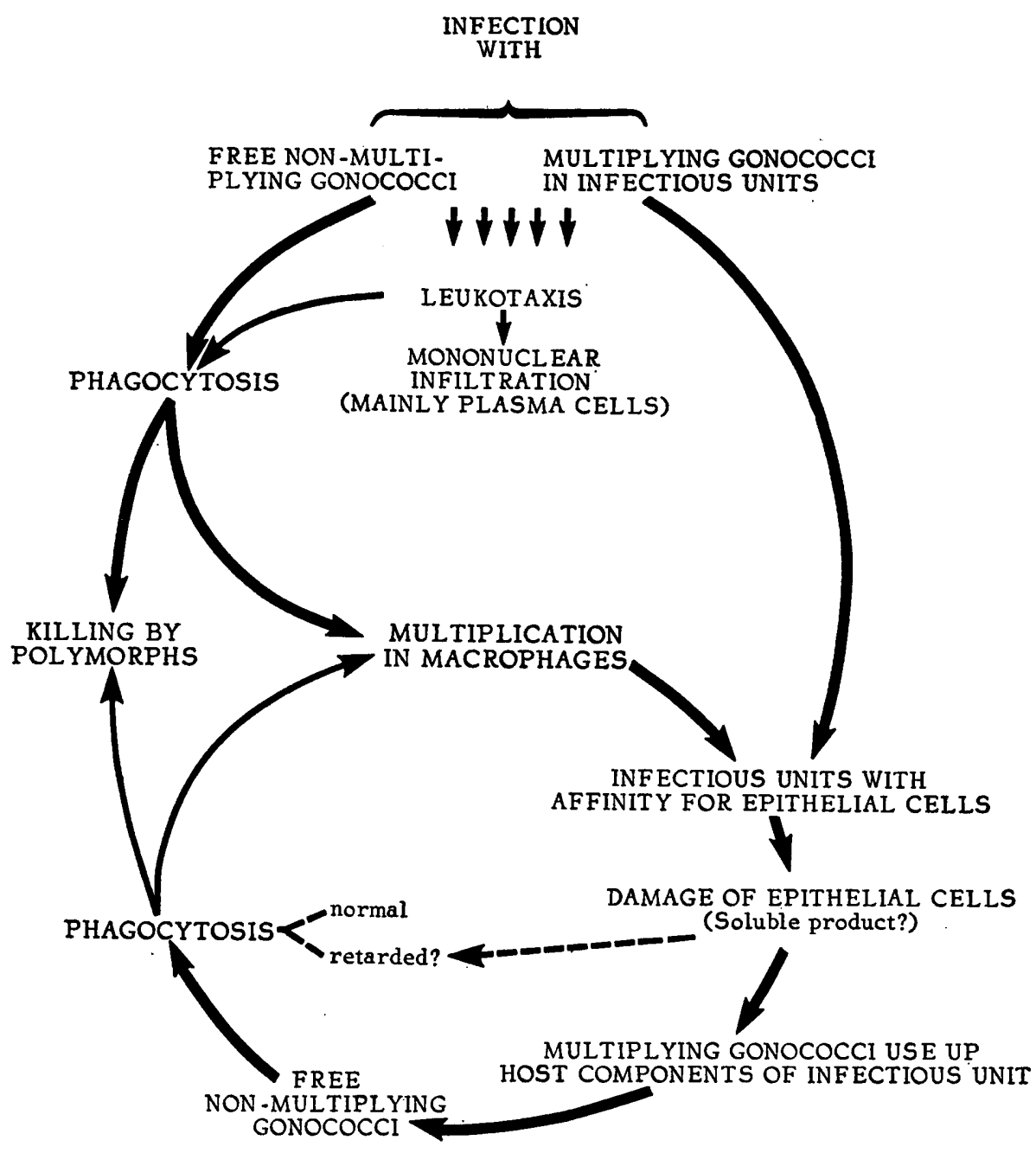

Fig. 22.-Summary of the infectious process in gonorrhoea. 
The possibility of gonococcal survival or delayed killing under experimental conditions in polymorphs has been raised recently by Thomas et al. (1973), Veale, Smith and Witt (1975) and Witt et al. (1976), but we do not have any evidence that infectious units can be formed in polymorphs. Polymorphs can take in a large quantity of gonococci, up to a self-destruction level; in general, however, the killing of gonococci by these phagocytic cells in pus appears to be a straightforward process and those gonococci that are eventually released are not coated with a dense granular coat.

3. The contact of gonococci in infectious units with epithelial cells appears to be mediated by the granules surrounding them (figs. 1-3 and 8); we assume that this association directly involves the granular coat. Many infectious units were seen on epithelial cells into which the peripheral granules had penetrated, or were resorbed, whereas the majority of cocci remained outside. When the gonococci were partially inside the epithelial cell (fig. 5 ), the whole unit with its granules was present. It seems that the presence of the infectious unit inside epithelial cells is the result of epithelial-cell activity and not primarily of gonococcal activity. This explanation is based on the observation that " invasion "was observed only in cases where the epithelial cell was morphologically intact. When the epithelial cell was damaged, as was observed in most cases, the infectious unit remained anchored only.

Inside many damaged epithelial cells with infectious units on their periphery, gonococcal antigen could be detected; it reacted strongly with anti-gonococcal rabbit or human sera labelled with horseradish peroxidase or with ${ }^{125}$ I. It is therefore possible that some gonococcal antigen was released during the multiplication of gonococci in infectious units and that this penetrated, or was resorbed, into epithelial cells without the intracellular presence of gonococci.

According to these findings we propose that human gonococcal infection may have the following sequence (fig. 22). The host is infected with a mixture of free, non-multiplying gonococci, and multiplying gonococci in infectious units. Infectious units make contact with epithelial cells. The presence of multiplying gonococci is highly leukotaxic and this leads to mobilisation of pus cells and to infiltration of the mucosa and submucosa of the urogenital tract. All free gonococci are phagocytosed. Those phagocytosed by polymorphs are destroyed whilst those taken up by mobilised mononuclear phagocytes interfere with the regulation of the cells and multiply. The multiplying gonococci become densely surrounded by the remnants of the host cell which is destroyed and a new infectious unit is formed. This process takes place in the superficial layer of the mucosa. Our difficulty in labelling gonococci in infectious units with anti-gonococcal sera may be attributable to the dense accumulation of granules around the gonococci protecting them against humoral defences and enabling them to go unrecognised by phagocytes for as long as the coat remains dense. As a result of multiplication of gonococci in infectious units, the host cell remnants are utilised; the gonococci become less and less coated and are rephagocytosed, and the cycle is repeated. Depending on the nature of the phagocytic cells involved, an abortive infection or a self-cure of gonorrhoea may occur. During the multiplication of gonococci in infectious units a soluble antigen, or more than one, is probably produced that can be detected in epithelial cells. It is not clear whether this antigen may influence the rate of phagocytosis in the later stages of the infection.

We assume that the presence of infectious units is important for the development of typical clinical symptoms of gonorrhoea. Experimental infection of 
human beings or chimpanzees with cultured gonococci produces a condition that differs in several respects from natural acute gonorrhoea (Kellogg et al., 1963; Kellogg et al., 1968; Arko et al., 1974; Arko et al., 1976). In our animal experiments the formation of true infectious units was never observed. However, it has been reported that for the survival of some gonococcal strains in mouse-chamber experiments the presence of tissue-culture cells invaded by cocci is important (Waitkins, 1975).

It was surprising that the fibrous tissue surrounding the chamber in guineapigs (Arko, 1972, 1974), although heavily infiltrated with pus cells when infected with gonococci, was never liquefied. During gonococcal infection the guinea-pig pus cells therefore do not exercise their full activity; such activity is apparent when the chamber is infected with other species such as $E$. coli. Since colchicine-an inhibitor of the activation of granules in phagocyteshad an immediate effect on the multiplication of gonococci in chambers, one may assume that the effect of gonococci on guinea-pig phagocytes is quantitatively, and most probably also qualitatively, different from that of colchicine.

Although the sera of rabbits immunised with gonococci contain antibodies that react with ring structures derived from naked endotoxin particles, the finding of large amounts of these antibodies in human serum was unexpected. On the other hand, the failure to detect pilar antibodies by immune electron microscopy in the sera of patients during and after gonococcal septicaemia was surprising because the sera were rich in IgG against other surface components. Initially we supposed that man, like the rabbit, has a poor immunological response to pilar antigen. Rabbits require extensive hyperimmunisation (Novotny and Turner, 1975) whereas in guinea-pigs potent anti-pilar antisera are produced after two intramuscular injections of gonococcal cultures in alum (unpublished observation). However, the most probable explanation is the high specificity of the pilar serotype. It is not unusual for a patient to be infected with several gonococcal strains at the same time, as judged by the pilar serotype marker (Novotny, Turner, Harris and Maclennan, 1975). As no isolates from blood cultures were available from these patients and only isolates from the urogenital tract were studied, the pilar serotype responsible for the generalised infection probably remained undetected. The one exception, where pili in culture reacted heavily (StG 176U), could be accounted for by postulating that the isolate obtained from the urethra of the patient was a mixed culture of several pilar serotypes of which one was detected after several negative experiments. However, our findings indicate that pilar antibodies are not readily formed against strains present in the urogenital tract and that the detection of such antibodies in patients' sera is unlikely to be a very sensitive diagnostic test.

We have abandoned the concept of pili as a mechanism of virulence enabling gonococci to anchor to mucosal cells (Swanson, 1973; Ward et al., 1974). Infectious units are anchored to epithelial cells in a different way. Whether the pilar antigen as such plays a significant role among the variety of particulate gonococcal antigens has still to be determined; we do not anticipate that pilar antibodies are likely to be important in protection (Turner and Novotny, 1976). 


\section{SUMMARY}

Gonococci in pus appear in specific clusters in which they are surrounded by organelles and granules derived from the host cells in which they multiplied. These clusters have been named infectious units because (1) the cocci multiply within them, (2) the whole complex makes contact with epithelial cells, (3) the cocci in the units are not recognised by polymorphs as long as the coating of granules is dense enough, and (4) the cocci are probably protected against humoral defence mechanisms. During multiplication of bacteria in infectious units, soluble antigenic material is probably produced. No morphological evidence of multiplication of gonococci outside infectious units was observed in pus from patients with gonorrhoea. Attempts to reproduce typical infectious units in animal models have so far failed.

The identity of the surrounding granular coating was established morphologically and with appropriate sera labelled with 125 I and horseradish peroxidase. It is proposed that the mechanism of gonococcal pathogenicity is primarily based on the internal disorganisation of the regulatory mechanism of human macrophages. A sequence of events in the infection is discussed.

The anatomical changes observed in subcutaneously implanted plastic chambers in guinea-pigs infected with gonococci may be attributable to partial interference with the internal regulation of phagocytes. The effect of drugs on bacterial counts in the chamber cavity was studied. Under the influence of colchicine the number of colony-forming units increased 100 times within $8 \mathrm{~h}$; vinblastine was without effect. Neither of these drugs had any effect on the growth of gonococci in vitro. In studies by immune electron microscopy with sera from patients with gonococcal septicaemia, IgG was shown to react strongly with the gonococcal surface, free endotoxin, ring structures (pits) liberated from the lipopolysaccharide backbone and with unspecified soluble antigenic material. The detection of pilar antibodies in these sera was rare.

We wish to thank Mrs H. Dear, Mr P. Hine, Miss S. McHardy, Mr P. Rowden, Miss F. A. Smith and $\mathrm{Mr} \mathrm{N}$. Woods for invaluable technical assistance and Dr L. Ivanyi for the supply of human peripheral phagocytes.

\section{REFERENCES}

ARKo, R. J. 1972. Neisseria gonorrhoeae: experimental infection of laboratory animals. Science, N.Y., 177, 1200.

ARKo, R. J. 1974. An immunologic model in laboratory animals for the study of Neisseria gonorrhoeae. J. infect. Dis., 129, 451.

Arko, R. J., Duncan, W. P., Brown, W. J., Peacock, W. L. and Tomizawa, T. 1976. Immunity in infection with Neisseria gonorrhoeae: duration and serological response in the chimpanzee. J. infect. Dis., 133, 441.

Arko, R. J., Kraus, S. J., Brown, W. J., Buchanan, T. M. and KuhN, U. S. G. 1974. Neisseria gonorrhoeae: effect of systemic immunisation on resistance of chimpanzees to urethral infection. J. infect. Dis., 130, 160.

Avrameas, S. And Ternynck, T. 1971. Peroxidase labelled antibody and Fab conjugates with enhanced intracellular penetration. Immunochemistry, 8, 1175. 
Baggioloni, M.. Hirsch, J. G. AND De Duve, C. 1970. Further biochemical and morphological studies of granule fractions from rabbit heterophil leukocytes. J. Cell Biol., 45, 586.

BULLEN, J. J. 1975. A new technique for recovering bacteria stored in liquid nitrogen. $J$. gen. Microbiol., 89, 205.

Burdett, I. D. J. ANd Murray, R. G. E. 1974. Septum formation in Escherichia coli: characterization of septal structure and the effects of antibiotics on cell division. $J$. Bact., 119, 303.

Caro, L. G., van Tubergen, R. P. ANd Kolb, J. A. 1962. High-resolution autoradiography. I. Methods. J. Cell Biol., 15, 173.

COHN, Z. A. AND WIENER, E. 1963. The particulate hydrolases of macrophages. I. Comparative enzymology, isolation, and properties. J. exp. Med., 118, 991.

DEPIERRE, J. W. AND KARNOVSKY, M. L. 1973. Isolation of a nuclear fraction from guinea pig polymorphonuclear leukocytes after controlled hypotonic homogenization. Biochem. biophys. Acta., 320, 205.

DeVoe, I. W. 1976. Egestion of degraded meningococci by polymorphonuclear leukocytes. J. Bact., 125, 258.

GiBBS, D. L. AND RoBERTs, R. B. 1975. The interaction in vitro between human polymorphonuclear leukocytes and Neisseria gonorrhoeae cultivated in the chick embryo. J. exp. Med., 141, 155.

HUNTER, W. M. 1973. Radioimmunoassay. In Handbook of experimental immunology, 2nd ed., edited by D. M. Weir, Oxford, 17.1.

James-Holmquest, A. N., Swanson, J., Buchanan, T. M., Wende, R. D. and Williams, R. P. 1974. Differential attachment by piliated and nonpiliated Neisseria gonorrhoeae to human sperm. Infect. Immun., 9, 897.

JePhCOTt, A. E., ReYN, A. AND BirCh-ANDERSEN, A. 1971. Neisseria gonorrhoeae. III. Demonstration of presumed appendages to cells from different colony types. Acta path. microbiol. scand., B79, 437.

Jollès, P. 1962. Lysozyme from rabbit spleen and dog spleen. In Methods in enzymology, edited by S. P. Colowick and N. O. Kaplan, New York, vol. 5, 137.

Kellogg, D. S., Cohen, I. R., Norins, L. C., Schroeter, A. L. And Reising, G. 1968. Neisseria gonorrhoeae. II. Colonial variation and pathogenicity during 35 months in vitro. J. Bact., 96, 596.

Kellogg, D. S., Peacock, W. L. Jr, Deacon, W. E., Brown, L. and Pirkle, C. I. 1963. Neisseria gonorrhoeae. I. Virulence genetically linked to clonal variation. J. Bact., 85, 1274.

Malawista, S. E. AND Bodel, P. T. 1967. The dissociation by colchicine of phagocytosis from increased oxygen consumption in human leukocytes. J. clin. Invest., 46, 786.

Michell, R. H., KarnovSKy, M. J. AND KarNovsky, M. L. 1970. The distributions of some granule-associated enzymes in guinea-pig polymorphonuclear leucocytes. Biochem. J., 116, 207.

Novotny, P. AND Brookes, J. E. 1975. The use of Bordetella pertussis preserved in liquid nitrogen as a challenge suspension in the Kendrick mouse protection test. J. biol. Stand., 3, 11.

Novotny, P., Short, J. A. AND WalkeR, P. D. 1975. An electron-microscope study of naturally occurring and cultured cells of Neisseria gonorrhoeae. J. med. Microbiol., 8, 413.

NovotNY, P. AND TURNER, W. H. 1975. Immunological heterogeneity of pili of Neisseria gonorrhoeae. J. gen. Microbiol., 89, 87.

Novotny, P., Turner, W. H., Harkis, J. R. W. And Maclennan, I. P. B. 1975. Serology of Neisseria gonorrhoeae pili as a possible tool in the epidemiology of gonorrhoea. Proc. Soc. gen. Microbiol., 3, 58.

OfeK, I., BeAchey, E. H. AND Bisno, A. L. 1974. Resistance of Neisseria gonorrhoeae to phagocytosis: relationship to colonial morphology and surface pili. J. infect. Dis., 129, 310. 
Ověrnnikov, N. M. AND DelektorskiJ, V. V. 1971. Electron microscope studies of gonococci in the urethral secretions of patients with gonorrhoea. Br.J. vener. Dis., 47, 419.

Pelc, S. R., Coombes, J. D. ANd Budd, G. C. 1961. On the adaptation of autoradiographic techniques for use with the electron microscope. Expl. Cell Res., 24, 192.

Pesanti, E. L. ANd Axline, S. G. 1975. Colchicine effects on lysosomal enzyme induction and intracellular degradation in the cultivated macrophage. J. exp. Med., 141, 1030.

Punsalang, A. P. and Sawyer, W. D. 1973. Role of pili in the virulence of Neisseria gonorrhoeae. Infect. Immun., 8, 255.

QUIE, P. G. 1975. Pathology of bactericidal power of neutrophils. Seminars in Haematology, $12,143$.

RABINOWITZ, Y. 1964. Separation of lymphocytes, polymorphonuclear leukocytes and monocytes on glass columns, including tissue culture observations. Blood, $23,811$.

SMITH, H. 1964. Microbial behaviour in natural and artificial environments. In Microbial behaviour " in vivo" and " in vitro ", Symposium 14, Society for General Microbiology, Cambridge, p. 1.

SMITH, H. 1972. The little-known determinants of microbial pathogenicity. In Microbial pathogenicity in man and animals, Symposium 22, Society for General Microbiology, Cambridge University Press, 1.

SMITH, L. DS. 1949. Clostridia in gas gangrene. Bact. Rev., 13, 233.

Swanson, J. 1972. Studies on gonococcus infection. II. Freeze-fracture, freeze-etch studies of gonococci. J. exp. Med., 136, 1258.

Swanson. J. 1973. Studies on gonococcus infection. IV. Pili: their role in attachment of gonococci to tissue culture cells. J. exp. Med., 137, 571.

Swanson, J., Kraus, S. J. AND Gotschlich, E. C. 1971. Studies on gonococcus infection. I. Pili and zones of adhesion: their relation to gonococcal growth patterns. J. exp. Med., 134, 886.

Swanson, J., Sparks, E., Young, D. and King, G. 1975. Studies on gonococcus infection. $X$. Pili and leukocyte association factor as mediators of interactions between gonococci and eukaryotic cells in vitro. Infect. Immun., 11, 1352.

Thomas, D. W., Hill, J. C. AND TYERYAR, F. J. JR, 1973. Interaction of gonococci with phagocytic leukocytes from men and mice. Infect. Immun., 8, 98.

Thongthai, C. AND SAWYER, W. D. 1973. Studies on the virulence of Neisseria gonorrhoeae. I. Relation of colonial morphology and resistance to phagocytosis by polymorphonuclear leukocytes. Infect. Immun., 7, 373.

TURNER, W. H. AND NovotNy, P. 1976. The inability of Neisseria gonorrhoeae pili to confer immunity in subcutaneous guinea-pig chambers. J. gen. Microbiol., 92, 224.

van Furth, R., Schuit, H. R. E. and Hijmans, W. 1966. The formation of immunoglobulins by human tissues in vitro. I. The methods and their specificity. Immunology, 11, 1 .

Veale, D. R., Smith, H. AND WITt, K. 1975. Penetration of penicillin into human phagocytes containing gonococci. Lancet, 1, 306.

WaITKINS, S. A. 1975. Effect of tissue culture cells in promoting prolonged survival of $N$. gonorrhoeae in artificial subcutaneous cavities of mice. Br. J. vener. Dis., 51, 376.

WARD, M. E. AND WATT, P. J. 1972. Adherence of Neisseria gonorrhoeae to urethral mucosal cells: an electron-microscopic study of human gonorrhoea. J. infect. Dis., 126, 601.

Ward, M. E., Watt, P. J. and Robertson, J. N. 1974. The human fallopian tube: a laboratory model for gonococcal infection. J. infect. Dis., 129, 650.

WASSERMAN, E. AND LeVINE, L. 1961. Quantitative microcomplement fixation and its use in the study of antigenic structure by specific antigen-antibody inhibition. J. Immun., 87 290.

Witt, K., Veale, D. R. ANd Smith, H. 1976. Resistance of Neisseria gonorrhoeae to ingestion and digestion by phagocytes of human buffy coat. J. med. Microbiol., 9, 1. 